\title{
Polemic of Mudik in Indonesia: How People Deal with Government Regulation Related to Covid-19
}

\author{
Agra Liz Tantri ${ }^{1}$, and Sukarjo Waluyo ${ }^{2}$ \\ ${ }^{1}$ Master of Literature Department of English Literature, Faculty of Humanities, Diponegoro \\ University, Semarang - Indonesia \\ ${ }^{2}$ Master of Literature Department of Indonesian Literature, Faculty of Humanities, Diponegoro \\ University, Semarang - Indonesia
}

\begin{abstract}
Indonesia has a variety of cultures and traditions that develop in society; one of them is mudik, or the tradition of returning to hometown after a month of fasting during Ramadan to celebrate Eid al-Fitr. This tradition is an example of Indonesia's religious, cultural system related to the migration movement from one area to another. For many people, especially Muslims, mudik (homecoming) is considered an important event. However, since Covid-19 has been occurring globally, the government decided to ban this traditional annual activity, and it causes pros and cons to society. This research is intended to analyze society's responses toward government regulation about the prohibition of mudik (homecoming) in 2021 due to Covid-19. Researchers used a quantitative descriptive method, namely utilizing data obtained through an online simple random sampling survey conducted on several Muslims and supported by literature studies. The result shows $64 \%$ of the respondents decided to follow the government regulation by not returning home this year. Based on the result, the existence of this (Addendum) Circular Letter of the Covid-19 Handling Task Force No.13, 2021 became a preventive way to restrain society from returning home for Eid al-Fitr this year.
\end{abstract}

\section{Introduction}

As of March $11^{\text {th }} 2020$, the World Health Organization officially declared the coronavirus or Covid-19 as a pandemic due to its rapid spread and expansion worldwide [1]. People who have been infected with this virus mostly have severe acute respiratory symptoms, start having a fever, cough, headache, and may lose their sense of taste and sense of smell. This pandemic has attacked many countries and caused many people to die around the world, including Indonesia. The recent record of WHO as 2nd May 2021, there have been $1,672,880$ confirmed cases of Covid-19 with 45,652 deaths in Indonesia [2]. There is a possibility for an increase in cases of Covid-19 in Indonesia since managing a big country with a large population is more complicated.

The pandemic of Covid-19 gets more complex for Indonesia because this country has high rates of migration, and people who migrate are spread all over the area in Indonesia. This situation could expand the spread of the Covid-19 since rapid and massive mobility is a possible factor for the spread of infectious diseases. The spread of Covid-19 throughout the world is a storyline of village-to-city connectivity and vice versa [3]. In Indonesia, migrating 
to get a better job or get a better facility such as education is a common thing for people to do. People from various regions in Indonesia migrate from their hometowns to other areas that are considered to increase their prosperous life. The migrants in Indonesia usually will return to their hometown at least once a year during religious holidays, for example, when celebrating Eid al-Fitr. The tradition of returning to the hometown happens because of the simultaneous movement from one area to another, which then becomes uncontrollable mobility in one period. This special tradition during Ramadan is usually carried out by migrants, especially Muslims in Indonesia, known as mudik (homecoming). Based on that condition, the government (the national Covid-19 task force) has decided to ban 2021 Eid alFitr mudik (homecoming), one of Indonesia's largest annual movements, to suppress the Covid-19 virus transmission.

For many Indonesians, the Eid al-Fitri mudik (homecoming) is not just simply going back home for a while, but it has a lot of meanings. This tradition is a golden opportunity to gather and celebrate a special moment with families after having completed a whole month of fasting, followed by people will be having long days off as national holidays from work and school to celebrate this joyous moment. For many Indonesian people, especially Muslims, this unique annual tradition has become a moment for people to go back to their roots, back to where they belong. Based on that explanation, the tradition of returning to hometown contains the aspects of spiritual, social, and psychological which becomes an obligation that seems must be done to achieve happiness and harmony in life. According to the United Nations, a migrant is a person who changes his place of residence from one political or administrative area to another. The most common reason why the society wants to migrate from their hometown to other more profitable regions economically is to obtain a better job or higher income [4].

Even though the tradition of returning to hometown has become an annual agenda in Indonesia, since 2020, this tradition could not be conducted as the previous years because the government has decided to ban the Eid al-Fitr mudik (homecoming) from controlling the transmission of the Covid-19. Based on the government regulation listed in Circular Letter of the Covid-19 Handling Task Force No.13, 2021, the ban would take effect from May 6 to 17 [5]. The President of Indonesia, Joko Widodo, in his speech on April 16th 2021 said the reason why the government banned the Eid al-Fitr mudik (homecoming) tradition this year is because the government does not want to repeat the same mistake when there was a spike in coronavirus cases during the 4 holiday periods last year. Mr President said that during the Eid al-Fitr holiday last year, there was an increase in daily cases of up to $93 \%$, with a weekly death rate of up to $66 \%$. The second increase in Covid-19 cases occurred during a long holiday on August 20-23, which resulted in an increase of up to $119 \%$ and a weekly death rate of up to $57 \%$. The third occurred during a long holiday from 28 October to 1 November 2020, which led to an increase in COVID-19 cases by $95 \%$ and an increase in weekly death rates reaching $75 \%$. The last happened during the year-end holidays from December 24 th 2020 , to January 3 rd 2021, increasing the number of daily cases reaching $78 \%$ and an increase in the weekly death rate by $46 \%$ [6].

Based on that data, the government officially banned the Eid alFitr mudik (homecoming) tradition this year. The government wanted to minimize the possibility of coronavirus transmission from the interactions between people from different regions. That announcement comes with pros and cons from the society, especially Muslim migrants in Indonesia who wanted to celebrate the end of the Holy month of Ramadan in their hometown with their families. This study aims to know the responses of Muslim migrants in Indonesia about the regulation and how they deal with this issue. 


\section{Literature Review}

The government of Indonesia has officially banned an annual tradition of Eid alFitr mudik (homecoming) for the second consecutive year. The prohibition was written in Circular Letter of the Covid-19 Handling Task Force No.13, 2021 and then expanded in Addendum Circular Letter of the Covid-19 Handling Task Force No. 13, 2021 that was announced and signed in the middle of the unbridled coronavirus contagion on April 21, 2021. This new regulation aims to prevent massive movement of people from one area to another, increasing the coronavirus transmission in Indonesia. The government appealed to the public to obey the regulations by not doing the Eid al-Fitr mudik (homecoming) tradition this year to help decrease the number of coronavirus cases. Based on the newest regulation, the ban of Eid al-Fitr mudik (homecoming) tradition would take effect from May 6 to 17, and then it was extended from April 22 to May 5 and May 18 to 24. The government instructed the society to postpone their plan to do homecoming this year and provide a solution to celebrate this festive season virtually.

The government issued a regulation banning homecoming this year as most of Indonesia's Muslim population has an annual movement of returning to hometown known as mudik Lebaran. Mudik or homecoming is categorized as a temporary migration because it happens spontaneously and temporarily. This temporary migration happened in a relatively short time without the intention of settling down [7]. Mudik is a tradition in Indonesia that becomes a special moment, especially for Muslims who celebrate Eid al-Fitr. Based on KBBI or Kamus Besar Bahasa Indonesia (Indonesia Dictionary), the meaning of mudik is an activity of migrants or migrant workers to return to their hometown. Homecoming activity in Indonesia is synonymous with an annual tradition that occurs before feast religious holidays; for example, it happened before Lebaran (Eid al-Fitr) [8]. The word mudik itself comes from the word "udik", which means upstream; back to its origin; back to the root or can be translated as going home in the kampong, which is always done by Indonesian people, especially Muslims, before the arrival of Eid celebrations. Javanese people translated mudik as mulih sedilik (pulang sebentar) or going home for a while (in a short time). By doing this mixed annual religious and cultural tradition, Indonesians, mainly Muslim migrants, can strengthen their relationship with their friends and relatives in their hometown.

Eid al-Fitr mudik (homecoming) has been a long-running tradition among Indonesians. This famous tradition is usually carried out by Muslims and almost all people in Indonesia who live out from their hometown. This tradition usually happens from 7 (seven) days before Eid until 7 (seven) days after the day. The Eid al-Fitr mudik (homecoming) is one kind of worship or annual tradition which does not recognize the socio-economic status or the degree of life. This unique tradition becomes a priority when facing the day of Eid al-Fitr in order to celebrate the festive season with families and relatives. No wonder many people will break any rules and barriers to meet their family in their hometown. [9]. The concept of visiting and returning home in mudik (homecoming) is tied to spirituality and cultural aspects. When religious and cultural aspects are combined, mudik (homecoming) becomes a customary tradition, not just a habit [10]. Based on that explanation, in order to celebrate this joyous Eid al-Fitr, migrants and especially Muslims in Indonesia used this golden moment as an opportunity to gather with family and relatives who were spread in other areas outside their hometown. Moreover, this moment is considered a perfect time to visit parents after living apart as a migrant and becomes a special moment to forgive each other during the holy month.

The mudik (homecoming) occurrence in Indonesia comes from the population's movement (migration or urbanization). The movement of the population happened after the independence of Indonesia or around the 60s-70s when many people were looking for work in the city or another place better than their village [11]. This homecoming phenomenon in 
Indonesia which was later identified with Lebaran, began to occur in the early-mid 1970s when Jakarta emerged as the only major city in Indonesia that was transformed into a metropolitan city in the $60 \mathrm{~s}-70 \mathrm{~s}$. In this case, Jakarta has become a city where people migrate from their hometown to get a better life. From that example, the relationship between the existence of migration and the mudik (homecoming) tradition in Indonesia can be found.

Besides, the relationship between migration and the spread of coronavirus itself was investigated in China. The research proved that migration from Wuhan before the lunar New Year boosts the comprehensive transmission of the virus. Migration activity between some significant areas became a vital role of the crucial issue in spreading the virus. The researchers said that the government should take strict ways to reduce migration and take profound control of the continuing spread of coronavirus [12]. That case was an example of how dangerous the movement of people in a public area was during a pandemic. Massive movement of people from one place to another by plane, ship, motorcycle or car plays a significant role in spreading Covid-19 in many places. Many people will meet, communicate, probably shake hands, and gather in one room during that time. Whereas those activities are not safe to do during a pandemic like now. Based on that phenomenon, corona cases in Indonesia can increase if the society is still doing mudik Lebaran (Eid al-Fitr homecoming tradition) this year.

\section{Result and Discussion}

The online random sampling survey was held on April 28th 2021, or fourteen (14) days before the day of Eid al-Fitr 2021, and followed by 50 respondents. The survey conducted online took a small and random portion of the entire population to represent the entire data. This online random sampling survey was followed by 50 Muslims Indonesian who have been migrating more than a year from their hometown to another area within Indonesia for work like the sample size. This survey aimed to obtain respondents' responses about the issue. From the survey, respondents' responses about the prohibition of homecoming during Eid alFitr 2021 were used as the primary data.

There were two groups of the respondents' responses after the government released the prohibition of Eid al-Fitr mudik (homecoming) this year. The first group consists of $64 \%$ of respondents who decided not to return to their hometown and celebrate this festive season virtually with their family as the government's recommendation. Another group consisted of $36 \%$ of respondents who intended to go on mudik (homecoming) this year even though the government inaugurated the regulation.

\subsection{Respondents Who Obeyed the Government Regulation}

Based Based on the survey, 32 respondents or $64 \%$ of the total, chose to follow the government's regulation by not going home to celebrate Eid al-Fitr this year. There were several reasons why they decided to obey the government's regulation regarding the prohibition of going home this year as written in (Addendum) Circular Letter of the Covid19 Handling Task Force No. 13, 2021.

Of the total 32 respondents who chose not to return to their hometown, $22 \%$ of respondents voluntarily decided to postpone their plans to return to their hometown and chose to obey the government regulations after knowing about that news. Moreover, another $22 \%$ of respondents answered why they chose to stay because they think it would be difficult to get permission and arrange any requirements to go for mudik (homecoming) this year. This happened because, based on some news from some media information, the government has prepared many officers and task force teams of Covid-19 to stay on the roads. The government has announced that the regional police of Metro Jaya has prepared 31 
checkpoints that would spread across the borders of DKI Jakarta, Bogor, Tangerang, Depok, and Bekasi (Jabodetabek) to oversee the implementation of mudik (homecoming) prohibition. A thousand personnel were deployed at those checkpoints in Jabodetabek to anticipate people still going for mudik (homecoming). The regional police of Metro Jaya has also prepared 77 security posts located in recreational areas, markets, and malls. Some checkpoints also scattered in other areas in Indonesia, especially at toll gate exits and entrances, such as at Ngawi - East Java toll gate, which was guarded by police and task force teams of Covid-19. The government prepared it to prevent mass travel, which could accelerate the spread of the Covid-19 virus across the country when millions of people travel to visit their families in their hometowns.

Furthermore, $19 \%$ of respondents have planned not to go for mudik (homecoming) since the beginning of this year because they realized this is not the right time to gather with many people in the middle of a pandemic like this. They were aware of becoming a carrier for the coronavirus and needed to protect themself, their family, and other people in their hometown as well. Another 19\% of respondents could not go for mudik (homecoming) this year because they got serious warnings from their offices/schools/institutions not to do Eid Fitr homecoming during this pandemic. The government warned state civil servants (ASN), members of the Indonesian Defence Armed Forces and Indonesian National Police, privatesector employees, state-owned enterprises employees (BUMN), entrepreneurs, and the public from returning to their hometown to celebrate Eid al-Fitr. The government instructed the whole Indonesian people to work together to overcome this pandemic and would give sanctions for those who violate the rules. The covid-19 task force teams also asked all regional governments to firmly enforce regulations of Eid al-Fitr mudik (homecoming) to prevent further spread of Covid-19 due to the potential increase in mobility during the Eid al-Fitr mudik (homecoming) session this year [13].

The government of Semarang was one of the regions that implemented the central government and the task force teams of Covid-19 regulations to ban the society from going to Eid al-Fitr mudik (homecoming) this year. Both civil servants and non-civil servants who have been registered in the staffing data of the Semarang system were required to be present through an official application every day from May 12 to May 16, 2021. That application can track the user's location, and if the employee is detected outside the designated areas, they must be prepared to receive sanctions. That rule was applied by Semarang's government to restrain its citizens from travelling out of the Semarang city. Moreover, $12 \%$ of respondents could not return to their hometown during this festive season because they still have essential work/agenda that must be completed. They admit that they do not get a day off from their office and complete some work according to a predetermined deadline. The last group, which consists of $6 \%$ of respondents, decided not to celebrate Eid al-Fitr in their hometown because their family advised them to obey the government's regulations. After all, the situation is not safe due to Covid-19. They planned to celebrate this holy moment by doing a video call with their family in their hometown.

\subsection{Respondents Who Refused the Government Regulation}

Contrary to those 32 respondents who decided to follow the government's regulation, 18 out of 50 respondents planned to celebrate Eid al-Fitr in their hometown. This group consisted of $36 \%$ of respondents who intended to go on mudik (homecoming) this year even though the government banned it. Based on some news, many people started to return home before the travel restrictions took effect. Toward the end of the holy month of Ramadan, many Indonesians from urban areas began to return to their hometowns even though the internal travel ban had been applied. For those respondents who decided to go on mudik (homecoming) this year, $50 \%$ of the respondents planned to ride a motorcycle or 
car, and the other $50 \%$ bought public transportation tickets (train/bus/plane) to take them home.

Some respondents who violated the government's regulation by still wanting to go to their hometown to celebrate Eid al-Fitr argued that everything would be safe because they got vaccinated and strictly applied health protocols such as prepared hand sanitizer and wearing masks, and social distancing. A total of 8 people, or $44 \%$ of 18 respondents, chose this statement because they believed that getting vaccinated and implementing health protocols would help protect them from the coronavirus. They believe that wearing a mask and prepared hand sanitizer help them to ward off the coronavirus. Other respondents answered that deciding whether to go for mudik (homecoming) or not is each individual's business. The number showed that $33 \%$ of respondents said it was their choice to go for mudik (homecoming) or not this year.

The other respondents answered that mudik (homecoming) is an important tradition as one of a series to celebrate the joyous moment of Eid al-Fitr. That reason was chosen by $11 \%$ of respondents because they would feel incomplete if they could not celebrate Eid al-Fitr in their hometown together with their family and relatives. One of the respondents named Afifa, who has been migrating to Jakarta for 2,5 years, said Eid al-Fitr is an important moment for her and her family, so she would return home to Semarang by plane. This special moment called Lebaran could reconnect all the families, asking for forgiveness, and renewing her spiritually.

Whereas, the numbers showed $6 \%$ of the respondents who chose the option of celebrating Eid al-Fitr at home because their family asked them to return home so they could celebrate Eid al-Fitr together like usual. Besides, another $6 \%$ of respondents stated that they had already bought tickets and prepared all other needs for their family and relatives, so they still intended to go home for a while this year to celebrate Eid al-Fitr at home.

\subsection{Polemic of Mudik (Homecoming) in Indonesia}

Since the COVID-19 handling task force already reminded regional governments to enforce the rules set by the central government as in (Addendum) Circular Letter of the Covid-19 Handling Task Force No. 13 of 2021, there were still many different opinions regarding the implementation of that regulation in various regional offices or institutions. According to Dr Windhu Purnomo as an epidemiologist, many officers in several locations are overwhelmed by an influx of travellers who are desperate to celebrate Eid al-Fitr at home during this holy month. It happened because the government makes policies that are quite contradictory and biased; they are out of sync and lack coordination between many sectors, the central and regional governments [14].

A number of $38 \%$ of respondents answered that their office suggested the employees obey the government regulation, but the final decision to go for mudik (homecoming) or not was on them. This case is an example of applying regulations that seem not well coordinated between the central and regional governments. Some offices still free their employees to decide whether to return home or not this year during the Eid al-Fitr holiday. Public confusion over those out-of-sync government policies has made the people refuse to obey the regulation.

A different case was experienced by one of the respondents named Yulita, a 26-yearold worker who has been living in Semarang for eight years. She decided to cancel her plan to go for mudik (homecoming) to her hometown in the Jepara regency because her office warned their employees to not go for mudik (homecoming) this year and would give sanctions to those who keep doing it. Yulita was one of $36 \%$ of respondents who could not return to their hometown because the office warned their employees to not go for mudik (homecoming). The rest of the respondents, or $26 \%$ of the total, said that their 
office allows the employees to go for mudik (homecoming) by following health protocols such as always wearing a mask, preparing hand sanitizer, taking swab test and the result must be negative and planned to follow the quarantine protocol once they arrived.

According to the survey, $60 \%$ of the total 50 respondents argued that (Addendum) Circular Letter of the Covid-19 Handling Task Force No.13, 2021 were not effective and efficient decisions to be applied right now. They wanted the government to be wiser in making decisions considering that many aspects had disadvantaged effects, such as sellers and the public transportation sector. That statement is in line with the statement from many street vendors that there is a decrease in buying and selling transactions in the market during Eid al-Fitr 2021. Moreover, for many Indonesians, especially Muslims, the Eid alFitr mudik (homecoming) is an important tradition that they must prepare for months ahead of Ramadan. Some have prepared souvenirs for relatives in their hometowns and bought train/plane/bus tickets to take them home.

The data showed that $28 \%$ of respondents said the regulation is a good decision and has appropriately applied even though it could not please everyone. Moreover, $8 \%$ of respondents who supported the government's program stated that the regulation should be applied right now and the government should have taken firm decisions and also sanctions for those who break the rules, so this pandemic would end sooner. Meanwhile, the number of respondents who objected to the existence of this government's regulation is $4 \%$ because they think that (Addendum) Circular Letter of the Covid-19 Handling Task Force No.13, 2021 could interfere with the continuity of the annual tradition to celebrate Eid al-Fitr with families and relatives in hometown.

Based on the survey, more than half of the respondents or $56 \%$, answered that the regulation is such a good anticipatory action from the government to suppress the spread of Covid-19 in Indonesia, but they were not sure this regulation could go well and smoothly. The statement is following the report of the Karawang Resort Police. As of May 8 until May 10, 2021, they have turned back more than 20.000 motorbike travellers who passed through checkpoints for Eid al-Fitr mudik (homecoming). On May 8, it was recorded that 1.445 motorbikes were forcibly turned back. On May 9, the number increased to 9.141 motorbikes, and on May 10, 2021, it doubled by 18.405 motorbikes [15]. Those data showed that the regulations that have been made by the government as written in (Addendum) Circular Letter of the Covid-19 Handling Task Force No.13, 2021 were not working properly because there were still many people who insisted on going home. Thousands of people who travel by motorcycles for their annual mudik (homecoming) rammed security barricades on the border of Bekasi - Karawang regency in West Java despite the Eid al-Fitr travel ban. It caused traffic congestion, and they forced the security officers to let them pass through to go home.

Furthermore, $26 \%$ of respondents said that the regulation is not an appropriate way to control the spread of Covid-19 in Indonesia, and they believe that many people will break the rules. That statement follows the result of the survey conducted by the Ministry of Transportation. Based on a survey, 18.9 million people still insist on going home this year [16]. The glory after a month of fasting makes the Muslim community is looking forward to reuniting with their family members and relatives in celebration of Eid al-Fitr together. Based on the statement of the Central Java Governor, Ganjar Pranowo, as of May 4, 2021, Central Java has been visited by more than 5000 people who have returned to their hometowns [17]. That mass mobility would be a reminder for the government to be aware of due to the spike in the number of Covid-19 after the Eid al-Fitr holiday. Even though most of the respondents stated that the regulation would not go well and work perfectly, $10 \%$ of respondents still believe that the regulation will run perfectly and will be well executed by the society even though it was not the best decision that could be applied right now. Lastly, only $8 \%$ of respondents believe that this regulation can be implemented properly and appropriate to prevent the spread of Covid-19 in Indonesia. 
Some people who refused to follow the rules considered this regulation to be implemented because there were many stores, theme parks, and restaurants open with many visitors during the pandemic. Meanwhile, not all people and those public spaces applied the high standard of health protocols. Although the government and the task force team have campaigned consistently to follow health protocols, people still could refuse to wear masks in public spaces. The existence of Iftar activity during the fasting month also caused a crowd and made the coronavirus spread faster, followed by a new cluster of Covid-19 behind.

\section{Conclusion}

The The existence of the (Addendum) Circular Letter of the Covid-19 Handling Task Force No.13, 2021 became a proper attempt to restrain society from going home for Eid alFitr this year. Despite the fact that the government's decision to ban Eid al-Fitr homecoming as the latest effort to suppress the Covid-19 virus transmission has not worked perfectly, at least it is a better way to prevent mass mobility.

The respondents who chose not to go for mudik (homecoming) this year consider safety and healthiness are the most important things right now. In order to end this pandemic, people must follow the rules and practice health protocols so Indonesia can suppress the spread of the coronavirus. Meanwhile, some respondents who were still doing mudik (homecoming) this year admit to being confused by the government's regulation and think the regulation is not the best choice to be implemented right now.

The government banned mudik (homecoming), but many restaurants, recreational parks, and department stores were full of visitors. Meanwhile, there has been friction between Indonesia's central government and regional governments over physical distancing standards, and there is no national lockdown in Indonesia to stem the spread of the Covid-19. Besides, confusion has arisen because the government still allows intercity transportation modes to operate during the travel ban. That statement could be a correction note for central and regional governments to work together as a great team to help the task force teams run the rules.

Although this regulation seems not to run perfectly because there were some people still trying to go for mudik (homecoming) and some of them already arrived at home, most of the respondents thought the regulation became an anticipating way to prevent the increase of coronavirus cases after the Eid holiday season. It could not be denied the Eid alFitr mudik (homecoming) is a tradition of our society. However, all Indonesian people will face dangers if the government allows it during this pandemic. Regarding the implementation of this prohibition, the respondents criticized the government and task force teams for evaluating this regulation better and more efficiently and effectively before being implemented to the public next time.

The prohibition is imposed because the government wants to protect all Indonesian people from Covid-19 transmission. Maintaining the safety and health, our family, relatives, and the surrounding environment is our responsibility. Working together as good teamwork between the government and all elements of society in combating the spread of coronavirus, the pandemic will pass soon. 


\section{References}

1. (2020), Rapid risk assessment: Novel coronavirus disease 2019 (COVID-19) pandemic: increased transmission in the EU/EEA and the UK - sixth update, Retrieved from https://www.ecdc.europa.eu/en/publications-data/

2. (2021), Update confirmed cases of Covid-19 in Indonesia, Retrieved from https://covid19.who.int/region/searo/country/id

3. I. Klaus, Pandemics Are Also an Urban Planning Problem, (CityLab New York City, 2020)

4. D. Villantina, Analisis Faktor-faktor yang Mempengaruhi Minat Migrasi ke Kecamatan Pedurungan, Skripsi S1 Fakultas Ekonomi UNDIP Semarang, (2008)

5. D. E. Nugraheny, (2021), Dimulai 6 Mei, Ini Rincian Aturan Larangan Mudik Lebaran 2021, Retrieved from https://nasional.kompas.com/read/2021/05/03/05440091/dimulai6-mei-ini-rincian-aturan-larangan-mudik-lebaran-2021?page $=$ all

6. Y. Medistiara, (2021), Alasan Lengkap Jokowi Larang Mudik Lebaran 2021, Retrieved from https://news.detik.com/berita/d-5535264/alasan-lengkap-jokowi-larang-mudiklebaran-2021

7. I. B. Mantra, Migrasi Penduduk Indonesia, (PPK - UGM Yogyakarta, 1983)

8. Arti Kata Mudik, (2021), Retrieved from kbbi.kemdikbud.go.id

9. B. B. Subyakto, Mudik Lebaran (Studi Kualitatif), Jurnal Ekonomi Pembangunan, 9(2), 61-67 (2011)

10. UNAIR News, (June, 2021), Memahami Fenomena Tradisi Mudik Menurut Dosen Sosiologi Unair, Retrieved from http://news.unair.ac.id/2019/06/07/fenomena-tradisimudik-menurut-dosen-sosiologi-unair/

11. (2021), Pakar Unair: Asal-usul Tradisi Mudik di Indonesia, Retrieved from Kompas.com

12. W. Y. Song, P. Zang, Z. X. Ding, et al., Massive Migration Promotes the Early Spread of COVID-19 in China: a study based on a scale-free network, Infect Dis Poverty, 9, 109 (2020)

13. (2021), COVID-19 Task Force Asks Regional Governments to Firmly Enforce Regulations on Eid Homecoming. Article by Office of Assistant to Deputy Cabinet Secretary for State Documents and Translation, Retrieved from setkab.go.id

14. (2021), Annual Homecoming Exodus Continues despite Internal Travel Ban in Indonesia, Retrieved from Kompas.com.

15. (2021), Pemudik Sepeda Motor Melonjak Setiap Hari, Retrieved from kompas.id

16. Kementerian Kominfo on Instagram, (2021), Hasil Survey Litbag Kementrian Perhubungan, Retrieved from Kementrian Kominfo Official Instagram.

17. (2021), Jawa Tengah Sudah Diserbu Pemudik, Retrieved from cnnindonesia.com 